\title{
THE IMPACT OF CLIMATE CHANGE ON RICE YIELD IN BANGLADESH: A TIME SERIES ANALYSIS
}

\author{
Iftekhar Uddin Ahmed Chowdhury, Mohammad Abul Earshad Khan, Lecturers \\ Faculty of Business Administration, BGC Trust University, Bangladesh \\ E-mail: iftekhar.chy2011@gmail.com, earshad ais@yahoo.com
}

\begin{abstract}
Rice is the staple food of about 158 million people of Bangladesh, but the increasing climate change vulnerabilities and global warming are severely reducing the yield of various rice crops and may threaten the food security in the country. Therefore, this study is undertaken to examine the potential impact of climate change on the yield of three different rice crops (namely, Aus, Aman and Boro) in Bangladesh. A multiple regression analysis using OLS method is employed to assess the climate-crop yield interrelations on the basis of country level time series data for the period 1972-2014. We find that all the climate variables have had significant impact on rice yield over the period under study, but these effects vary among three different rice yields. Our findings also reveal that maximum temperature is statistically significant and negatively affect the yield of all three rice crops. In contrast, minimum temperature is highly significant and have positive impact on the yield of Boro rice only. Furthermore, rainfall is found significant for all rice yields with positive effects on Aus and Aman rice and adverse effects on Boro. However, humidity has a statistically significant effect on the yield of all three rice crops. Nevertheless, the influences of maximum temperature and rainfall are more prominent compared with that of minimum temperature and humidity on rice yield in Bangladesh. Our findings emphasize the importance of adaptation of temperature-tolerant rice varieties, and suggest that sustainable agricultural development may play a vital role in mitigating adverse climate change effects.
\end{abstract}

\section{KEY WORDS}

Bangladesh, climate change, food security, rice yield, time series analysis.

Climate change, by its very nature, will alter temperature and rainfall patterns. Since agriculture is dependent on weather and crops are known to suffer yield losses when temperatures are too high, there is concern that warming caused by climate change will lower crop yields and threaten the food security in many parts of the world. Changes in rainfall might also cause reductions in yields, though at least in some places, changes in rainfall could lead to increases in yields (McCarl et al., 2001; Schmidhuber and Tubiello, 2007). Thus climate is the fundamental determinant of agricultural productivity. It is important especially in the case of developing countries like Bangladesh where agriculture is highly dependent on natural phenomena against the controlled environmental condition in developed countries. Bangladesh is a developing country with high population density where $(26.2 \%)$ of its total population lives under poverty and a huge proportions (roughly $66 \%$ ) of its total population derive their livelihoods from farms and forests (i.e., agriculture) (BBS, 2014). Rice is the principal food of our people and grown in this country from time immemorial. It contributes for about $92 \%$ of the total food grains produced in the country and covers about $77 \%$ of agricultural land. Bangladesh is the fourth largest rice producer in the world. At present, rice occupies 11.42 million hectares of land and produces about 33.6 million metric ton (DAE, 2013). In spite of technological progress (such as improved crop varieties and irrigation potentialities), climate is still a key determinant for agricultural productivity and sustainability in this country.

Bangladesh is extremely vulnerable to the impact of climate change, in part because it is a low- lying and very flat country, subject to riverine flooding and vulnerable to sea level rise. The confluence of three great rivers-the Padma, the Brahmaputra, and the Meghna makes the country a great deltaic plain. The extensive floodplains are the main physiographic features of the country. Both riverine flooding and sea level rise can result in inundation of crops; sea water, in particular, can result in salinization, causing permanent 
loss of currently productive agricultural land. Besides, the biggest mountain Himalayas in the north and the funnel-shaped Bay of Bengal in the south have made Bangladesh a meeting point of the life-long monsoon precipitations and the catastrophic devastation of floods, droughts, cyclones, storm surges, etc.(Ferdous and Baten, 2011). The climate of Bangladesh is characterized by high temperatures, heavy rainfall, high humidity, and fairly marked seasonal variations. More than 80 percent of the annual precipitation of the country occurs during the southwestern summer monsoons, from June through September during which Aman rice is grown and the remaining 20 percent covers rest of the eight months, including the winter season (dry season) and pre-monsoon season during which the high-yielding rice Boro and Aus is grown respectively. In recent years the weather pattern has been erratic, with the cool, dry season having considerably decreased-a change probably attributable to climate change. According to UNDP report (2008), the country has been facing higher temperatures, particularly during the monsoon over the last three decades. Furthermore, the country is forecasted to a rise in annual mean temperatures of $1^{\circ} \mathrm{C}$ by $2030,1.4{ }^{\circ} \mathrm{C}$ by 2050 and $2.4^{\circ} \mathrm{C}$ by 2100 (IPCC, 2007). However, the prediction for the winter season mean temperature also showed a similar rising pattern of $1.1^{\circ} \mathrm{C}$ by $2030,1.6^{\circ} \mathrm{C}$ by 2050 and $2.7^{\circ} \mathrm{C}$ by 2100 . While the projected value is $0.8^{\circ} \mathrm{C}$ by $2030,1.1^{\circ} \mathrm{C}$ by 2050 and $1.9^{\circ} \mathrm{C}$ by 2100 for the monsoon season (Agrawala et.al., 2003; Ahmed, 2006). Based on the above projections, it can be said that Bangladesh is likely to face more hot days and heat waves, longer dry spells and is in the higher drought risk. In general, temperature increase will have adverse effects on the yields of major food crops, especially rice and quality of food-crops thereby exacerbating vulnerability in food supply. As it's predicted that rice production is likely to fall by $8 \%$ to $17 \%$ by the year 2050 (IPCC, 2007; BBS, 2008).

Climate change in Bangladesh is an especially serious concern because agriculture is an important sector in the country. It contributes roughly 16 percent to gross domestic product (GDP), with crops representing 9.1 percent, livestock 1.8 percent, fisheries 3.7 percent, and forestry 1.7 percent (Bangladesh Bank, 2014). Furthermore, the sector provides employment and income to some of the poorest and most vulnerable members of society. However, aggregate domestic production and per capita availability of cereals have increased in the country over the past decades. Nevertheless, the country still depends on import of food grains (Rahman and Parvin, 2009). But the annual requirement for staple food is increasing and exceed supply, indicating that demand is higher than production (Begum and D'Haese, 2010). Thus, it is required to increase the rice yield in order to fulfill the growing demand for food originating from population growth. Climate change is a potential threat towards achieving the above mentioned objective. It is therefore at most important to realize the potential effects of climate change on the production of major cereal (i.e., rice) crop in Bangladesh under sustainable environmental conditions. Despite such a high degree of vulnerability to climate change for agriculture vis-à-vis welfare, very few studies have intensively examined the relationship between climate change and different crop (i.e., rice) yields in Bangladesh. Therefore, the purpose of this paper is to undertake a more comprehensive analysis of the impact of four important climate variables (namely, maximum temperature, minimum temperature, rainfall and humidity) on the yield of three different types of rice (namely Aus, Aman and Boro) crops in Bangladesh using countyspecific historical data for the period 1972-2014.

The remainder of this paper is organized as follows: in the literature review part, a visit of climate change studies focusing on agriculture (food crops) and a discussion of several key research approaches are discussed. In the next section we describe the climatic properties of different rice crops. Then in the methodology part, this paper introduces an empirical model to determine how climate variables affects the yield of three different rice crops. After that, this paper displays and discusses the model results. Finally, the paper concludes and discusses about the future research.

Previous Studies. There is a growing body of literature in recent years that has observed the influence of climate change on agricultural productivity. The scientific community has long argued that changes in climatic variables such as temperature and rainfall significantly impact crop yields. Reilly et al. (1996) found that as temperatures move 
away from the favorable growing temperature of crops, the growth of the crop is adversely affected. Similarly, if variability in temperatures is high, crop yields are lower. The authors conclude that places that are too hot or are too close to the optimum temperature are likely to suffer the most. Earlier studies on the influence of climate change on agriculture have focused on developed countries, predominantly the USA (Kaiser et al., 1993; Mendelsohn et al., 1994; Adams et al., 1995; Rosenzweig, 1989; Kim and Pang, 2009; Carew et al., 2009; Isik and Devadoss, 2006; Chen et al., 2004; Lobell and Asner, 2003; Stooksbury and Michaels, 1994). Despite such a high degree of vulnerability to climate change for agriculture vis-à-vis welfare in developing countries, there are very limited researches conducted in case of developing countries (Boubacar, 2010; Holst et al., 2010; You, et al., 2005; Mendelsohn, 2009; Lansigan et al., 2000; Chang, 2002; Gbetibouo and Hassan, 2005; Kurukulasuriya and Ajwad, 2007; Kabubo-Mariara and Karanja, 2007; Haim et al., 2008; Sanghi and Mendelsohn, 2008; Deressa and Hassan, 2009; Moula, 2009; Wang et al., 2009) and very few in case of Bangladesh (Sarker et al., 2014, 2012; Basak et al., 2013, Hossain and Silva, 2013; Hossain et al., 2012; Sarker, 2012; Basak et al., 2010; Mahmood, 1998; Paul, 1998; Ali, 1999; Rahman, 2000; Rashid and Islam, 2007).

Bangladesh is one of the countries where crop production is most likely to suffer adverse impacts from anthropogenic climate change. Besides, due to the large share of the agricultural sector in the overall output of the country's economy, the study of climate change impacts on Bangladesh agriculture has achieved recent attention. Karim et al. (1996) conducted a simulation study to assess the vulnerability of food grain production (rice and wheat) in six locations of Bangladesh to potential climate change such as enhanced $\mathrm{CO}_{2}$ and temperature. The results of the study showed that increased levels of $\mathrm{CO}_{2}$ increased yields of rice in all locations. Rimi et al. (2009) have conducted a study on the trend and prediction of future climate change scenarios with Global Climate Model (GCM) to examine the impacts of climate change on rice production. The study concluded that temperature variations had spectacular implications on crop yield. The production of Aus rice (summer crop) has decreased significantly with increasing maximum temperature, whereas the production of Boro rice (winter crop) has increased significantly with the increase of minimum temperature. The inter-annual fluctuation in the amount of winter season rainfall was little. Boro production, therefore, was insignificantly affected by this variable. However, correlation between the climatic variables and crop production was not statistically significant. In most situations, the study found that irrespective of crops and GCMs, climate change would have a negative effect on rice yield. Another study conducted by Awal and Siddique (2011) estimated the trend of rice production by employing ARIMA model but they did not consider climate influence. Hossain and Silva (2013) have conducted an initiative to find out the climate change impact on rice and wheat yield in Bangladesh. Their study concluded that global warming is expected to severely reduce the yield of various crops, including rice and wheat, directly affecting the food security of 160 million people in Bangladesh. However, this study only reviewed the past studies. Sarker et al. (2012) carried out a study to examine the relationship between three climate variables (maximum temperature, minimum temperature and rainfall) and three different rice crops (Aus, Aman and Boro). They considered 1971-1972 fiscal years' yield as the yield of 1972. However, to ensure consistency between climate parameters and yield, the authors accounted 1972's climate for 1972's yield. Actually, the previous (1971) year's climate data should be calculated for Aus and Aman rice as their growing season completely fell in this year. In case of calculating climate data for Boro rice, it should merge two calendar years data into one (for example, from December of 1971 to May of 1972 for 1972's yield), as they considered the growing months for Boro rice to be December-May. That is why their study might not represent the real relation between climate change and crops yield. In addition, the authors did not considered humidity as climate variable although this variable has significant influence on crop production.

However, very few studies have been done in Bangladesh to investigate the pattern and trend of rainfall, temperature, relative humidity, solar radiation, heat budget and energy balance on various ecosystem, and meteorological application on rice production. However 
from the previous studies conducted in Bangladesh, it was evident that very few of them have intensively examined the relationship between climate change and crop production (Ferdous and Baten, 2011). Accordingly, crop-oriented research (particularly on major staples) is pledged to formulate better policy suggestions for sustainable development. Given the high dependence of rice yield on climate variables (i.e., change), there is a vital need to assess the potential impacts of climate change (i.e., maximum temperature, minimum temperature, rainfall and humidity) on different types of rice yields (productivity). Because an understanding of the national impacts of recent climate trends on major food crops would help to anticipate impacts of future climate changes on the food security of the country.

Climatic Properties of different Rice Crops. Bangladesh is mainly a low-lying plain of about $144,000 \mathrm{~km}^{2}$, situated on deltas of large rivers flowing from the Himalayas. It has a tropical humid climate characterized by wide seasonal variations in precipitation, warm temperatures and high humidity (Rashid, 1991). There are three different seasons in Bangladesh: a hot, humid summer from March to June; a cool, rainy monsoon season from June to October; and a cool, dry winter from October to March. In general, maximum summer temperatures range between $30^{\circ} \mathrm{C}$ and $40^{\circ} \mathrm{C}$. April is the warmest month in most parts of the country. January is the coldest month, when the average temperature through the country is about $10^{\circ} \mathrm{C}$. However, rainfall in Bangladesh is not uniform throughout the country. With the exception of the relatively dry northwest part of the country, where the annual average rainfall is about $1,600 \mathrm{~mm}$, whereas most parts of the country receive at least $2000 \mathrm{~mm}$ of rainfall per year. Because of its location just south of the foothills of the Himalayas, where monsoon winds turn west and northwest, the regions in northeastern Bangladesh receives the greatest average precipitation, sometimes over $4000 \mathrm{~mm}$ per year. Approximately 80 percent of Bangladesh's rainfall occurs during the monsoon season.

The crop-growing period in Bangladesh is divided into two main seasons, Kharif and Rabi. Kharif season starts in May when the moisture supply from rainfall is enough to support rain-fed or unirrigated crops and ends in October. Rabi season (November to April) covers the months having no or very little rainfall. It starts at the end of the humid period and lasts up to the pre-monsoon season. In addition to these two main seasons, another transition season called Pre-Kharif can be identified. Pre-Kharif season (March to May) is characterized by unreliable rainfall that varies in time, frequency, and intensity from year to year, and provides only an intermittent supply of moisture for crops.

Rice is the primary cereal crop of our country. Three major rice crops (namely, Aus, Aman and Boro) constitute $100 \%$ of total rice production and it is grown throughout the country year-round in Bangladesh (with often 2-3 crops per year on the same land). These are grown in mutually exclusive seasons: as pre-monsoon crop, direct seeded and transplanted Aus rice (Kharif-1) from March to July, wet season transplanted Aman rice (Kharif-11) from June to November and dry season irrigated Boro rice (Rabi) from November to May (BBS, 2014). To some extent, this common rice crops calendar varies slightly from place to place depending on soil texture and land elevation. The crop calendar of different rice crops with their corresponding growing seasons is shown in table1.

Table 1 - Growing seasons of different rice crops

\begin{tabular}{|c|c|c|}
\hline Name of the Crop & Month & Growing Season \\
\hline Aus rice & March to July & Pre-monsoon (Kharif-1) \\
\hline Aman rice & June to November & Monsoon (Kharif-11) \\
\hline Boro rice & November to May & Winter (Rabi) \\
\hline
\end{tabular}

Source: Department of Agricultural Extension (DAE), Bangladesh.

Medium high land to lowland is suitable for rice cultivation depending on growing season namely: the summer (March-June), the monsoon (July-October) and the winter (November-February). Any land type can be brought under rice cultivation; but its cultivation may not be economical. Clay and loamy, slightly acidic to slightly alkaline soils are suitable for rice cultivation. Climate has always played a vital role in rice production. Aus rice requires supplementary irrigation during the initial stage of its growing season while Aman is almost 
completely rain-fed rice that grows in the months of monsoon, although it requires supplementary irrigation during planting and sometimes in the flowering stage depending on the availability of rainfall (BRRI, 1991). However, only $5 \%$ of Aman rice and $8 \%$ of Aus rice are irrigated (Ahmed, 2001). In contrast, Boro is fully irrigated rice grown in the dry winter and the hot summer (Mahmood, 1997). Nevertheless, according to BBS (2014), Boro is the most important crop in Bangladesh in respect of volume of production. Aman is the second largest crop in the country in respect of the volume of production and Aus is the third largest crop after Aman rice.

\section{METHODOLOGY}

Empirical Model Specification. The aim of this study is to examine the relationship between yield of three different rice crops (namely, Aus, Aman and Boro) and climate variables (namely, maximum temperature, minimum temperature, rainfall and humidity) to estimate the potential effects of climate change on rice crop productivity level. The dependent variable in this study is yield of different rice crops (such as, Aus, Aman and Boro) and following Lobell et al. (2007), Almaraz et al. (2008) and Sarkar et al. (2012) we have considered four climate variables as independent variable, that includes maximum temperature, minimum temperature, rainfall and humidity. Previous studies used different units of time, such as months, phonological periods and growing seasons, for climate variables. However, this study has used an average growing season maximum temperature and minimum temperature variables with average growing season rainfall and humidity variables, because the average growing season climate variables are able to capture the net effect of the entire range of the development process by which yields are affected by climate (Lobell and Field, 2007). Moreover, the average growing season temperature is a key determinant of average yield (Cabas et al., 2010). The monthly average growing season maximum and minimum temperature and the avearge growing season rainfall have been used in previous studies (Granger, 1980; Chang, 2002; Lobell and Field, 2007; Lobell et al., 2008).

Most of the studies on the possible impacts of climate change on food crops used indirect crop simulation models (Schlenker and Roberts, 2008) and regression models (Sarkar et al., 2012; Boubacar, 2010; Mendelsohn, 2009; Isik and Devadoss, 2006; You et al., 2005; Peng et al., 2004). Forecasts of the yield changes in response to changes in climate variables, from regression models based on historical climatic and yield data for specific crops are relatively accurate (Lobell and Asner, 2003; Lobell and Field, 2007; Mendelsohn et al., 1994; Lobell et al., 2007). Before estimate our model, at first we have checked the distribution of the yield of each rice crops (Aus, Aman and Boro) against time by drawing histograms. An inspection of the histograms shown that the yields of Aus, Aman and Boro rice seemed to follow a normal distribution. Thus, depending on the distribution of the yields (dependent variables) here we have chosen ordinary least squares (OLS) regression method to estimate three different rice crop models. However, there exists a significant and positive trends between rice yield and time. The results of the rice yields may vary due to change in non-climatic factors such as improved variety, management techniques, fertilizers, etc. Therefore, we need to remove the yield trend caused by non-climatic factors before run our linear regression model. In order to remove its trend and avoid heteroskedasticity in linear regression model, we can use log-linear regression model. Because log-transformation can transform absolute differences into relative differences. In this regard, we run the loglinear version of our regression models. Thus, on the basis of the distribution of the yields of three rice crops and other properties, the following regression models are employed:

The Aus Rice Model:

$$
\operatorname{lnYAus}_{\mathrm{t}}=\alpha_{0}+\beta_{1} \ln \max T_{t}+\beta_{2} \ln \min T_{t}+\beta_{3} \ln \text { Train }_{t}+\beta_{4} \ln \text { Hum }_{t}+\varepsilon_{t}
$$

where: 'InYAus' is the natural logarithm of yield of Aus rice (in metric ton per hectare), 
'InmaxT' is the log of growing season average maximum temperature $\left({ }^{\circ} \mathrm{C}\right)$ from March to July, 'InminT' is the log of growing season average maximum temperature $\left({ }^{\circ} \mathrm{C}\right)$ from March to July, 'InTrain' is the log of growing season average total rainfall (millimeter) from March to July, 'InHum' is the log of growing season average humidity (\%) from March to July, ' $\varepsilon_{t}^{\prime}$ is the error term and ' $\mathrm{t}$ ' is the time (i.e., year).

The Aman Rice Model:

$$
\operatorname{lnYAman}_{\mathrm{t}}=\gamma_{0}+\beta_{1} \ln \max T_{t}+\beta_{2} \ln \min T_{t}+\beta_{3} \ln \text { Train }_{t}+\beta_{4} \ln \mathrm{Hum}_{t}+\omega_{t}
$$

where: 'InYAman ${ }_{t}$ is the natural logarithm of yield of Aman rice (in metric ton per hectare), 'InmaxT' is the log of growing season average maximum temperature $\left({ }^{\circ} \mathrm{C}\right)$ from June to November, 'InminT' is the log of growing season average maximum temperature $\left({ }^{\circ} \mathrm{C}\right)$ from June to November, 'InTrain' is the log of growing season average total rainfall (millimeter) from June to November , 'InHum' is the log of growing season average humidity (\%) from June to November, ' $\omega_{t}$ ' is the error term of Aman rice model and ' $t$ ' is the time (i.e., year).

The Boro Rice Model:

$$
\operatorname{lnYBoro}_{\mathrm{t}}=\theta_{0}+\beta_{1} \ln \max T_{t}+\beta_{2} \ln \min T_{t}+\beta_{3} \ln \text { Train }_{t}+\beta_{4} \ln \text { Hum }_{t}+\Psi_{t}
$$

where: 'InYBoro' is the natural logarithm of yield of Boro rice (in metric ton per hectare), 'InmaxT' is the log of growing season average maximum temperature $\left({ }^{\circ} \mathrm{C}\right)$ from November to May, 'InminT' is the log of growing season average maximum temperature $\left({ }^{\circ} \mathrm{C}\right)$ from November to May, 'InTrain' is the log of growing season average total rainfall (millimeter) from November to May, 'InHum' is the log of growing season average humidity (\%) from November to May, ' $\Psi_{t}$ ' is the error term of Boro rice model and ' $t$ ' is the time (i.e., year).

In all cases, the a priori expectation is that the food crops that we grow need specific weather to survive, such as the optimum temperature, soil moisture (water), and atmospheric humidity. A change in climate could have both helpful and harmful effects on crops yield. Maximum and minimum temperature benefits crop production by enhancing photosynthesis thereby increasing crop yield as it increases However, extremely high temperature differentially affects the tremendous metabolic processes of plants, including the stability of various proteins and membranes and the effectiveness of enzymatic reactions in the cell which causes denaturation and finally metabolic imbalance. On the other hand, very low temperature may cause chilling injury in plants and precipitation increase affects crop yield positively by readily dissolving the nutrients for easy soil absorption by plants. Unfortunately, intense rainfall during the monsoon season can also lead to soil erosion or the wash-out of surface soil and the depletion of plant nutrients in soil due to runoff (IPCC, 2001). Similarly, farmers can suffer production losses as a result of the insufficient and erratic precipitation during the rainy season Very high or very low relative humidity is not advantageous for higher grain yield. Crops tend absorb soil nutrients for optimum yield when there is sufficient humid air. Relative humidity directly controls the plant-water relationships and indirectly influences leaf growth, photosynthetic rates, pollination, occurrence of diseases and ultimately crop yields. Moreover, atmospheric dryness can seriously threaten dry matter production through stomatal control and leaf water potential Thus, changes in climate would be likely to have various significant impacts on crops.

Data sources and properties. Secondary data on maximum and minimum monthly average temperature, monthly average total rainfall and humidity data for the last 43 years (1972-2014) has been collected from all 34 weather stations of Bangladesh Meteorological Department (BMD) located all over the Bangladesh. These year-wise monthly data are then converted to seasonal average data according to the growing periods for three different rice crops, such as Aus, Aman and Boro. While annual yield data of three different rice (Aus rice, 
Aman rice and Boro rice) crops in the time span 1972-2014 were collected from various issues of the Yearbook of Agricultural Statistics of Bangladesh (2011, 2012), Department of Agricultural Extension (DAE), various issues of the Bangladesh Economic Review (1991, 2010, 2011, 2012, 2013), and website of the Bangladesh Bureau of Statistics (BBS), and Bangladesh Bank. Yield data were found as the fiscal year basis, such as 1971-1972, 19721973 , etc. Then, these fiscal year data were transformed to yearly data, for example, 19711972 was considered as 1972. In case of Aus and Aman rice, the length of growing season considered as from March-July and June-November respectively and climatic variables have been defined for this time period. However, the growing period for Boro rice has been counted from November-May, which falls completely two different calendar years. Thus, the study came to the point that, in order to make a consistency between climatic variables and yield data, 1971's climate data were used against 1972's yield particularly for Aus and Aman rice. Similarly, the previous year (1971) and next year (1972) climate data were merged for 1972's yield for Boro, as this crop growing period is distributed into two calendar years.

The summary statistics of all the data series used in this study are presented in table 2. This table 2 also demonstrates the basic properties of the variables under study during three rice growing seasons in Bangladesh.

Table 2 - Summary Statistics of the data series for the period 1972-2014

\begin{tabular}{ccccccccc}
\hline \multirow{2}{*}{ Variables } & $\begin{array}{c}\text { Rice } \\
\text { Varietie }\end{array}$ & \multicolumn{7}{c}{ Statistics } \\
\cline { 3 - 8 } & s & Mean & Median & Max. & Min. & $\begin{array}{c}\text { Std. } \\
\text { Dev. }\end{array}$ & $\begin{array}{c}\text { Skewnes } \\
\text { s }\end{array}$ & Kurtosis \\
\hline \multirow{2}{*}{ Yield } & Aus & 1.263 & 1.100 & 2.300 & 0.770 & 0.380 & 1.114 & 3.448 \\
$($ ton/hac) & Aman & 1.612 & 1.560 & 2.370 & 0.980 & 0.384 & 0.388 & 2.062 \\
& Boro & 2.767 & 2.530 & 3.970 & 1.800 & 0.663 & 0.486 & 2.050 \\
\hline \multirow{2}{*}{ MaxT } & Aus & 32.418 & 32.432 & 33.713 & 30.682 & 0.486 & 0.760 & 3.346 \\
$\left({ }^{\circ} \mathrm{C}\right)$ & Aman & 30.601 & 30.531 & 31.355 & 29.969 & 0.410 & 0.319 & 2.059 \\
& Boro & 29.425 & 29.297 & 30.776 & 29.224 & 0.748 & 1.083 & 4.324 \\
\hline \multirow{2}{*}{ MinT } & Aus & 23.599 & 21.305 & 25.225 & 20.622 & 1.654 & 4.995 & 8.593 \\
$\left({ }^{\circ} \mathrm{C}\right)$ & Aman & 24.225 & 24.237 & 25.134 & 23.615 & 0.299 & 0.494 & 3.827 \\
& Boro & 19.194 & 19.062 & 19.190 & 17.837 & 3.978 & 5.124 & 9.387 \\
\hline \multirow{3}{*}{ Rainfall (mm) } & Aus & 204.170 & 206.402 & 345.274 & 81.130 & 38.433 & 0.577 & 7.993 \\
& Aman & 328.848 & 323.211 & 564.896 & 230.711 & 55.026 & 1.783 & 9.252 \\
& Boro & 94.921 & 88.629 & 184.342 & 37.741 & 30.921 & 0.607 & 3.236 \\
\hline \multirow{2}{*}{ Humidity } & Aus & 79.557 & 79.821 & 82.449 & 76.250 & 1.679 & -0.310 & 2.020 \\
$(\%)$ & Aman & 84.304 & 84.353 & 86.868 & 82.054 & 1.193 & -0.164 & 2.397 \\
& Boro & 74.275 & 74.941 & 78.753 & 68.488 & 2.465 & -0.331 & 2.341 \\
\hline
\end{tabular}

Note: MaxT= growing season maximum temperature ( $\left.{ }^{\circ} \mathrm{C}\right) ; \operatorname{Min} T=$ growing season minimum temperature $\left({ }^{\circ} \mathrm{C}\right)$, ton/hac $=$ ton per hectare, $\mathrm{mm}=$ millimeter.

Source: Authors' own estimation based on DAE, BBS and BMD.

It is evident from table 2, that mean yield of Boro rice is the highest and more than twice as high as that of Aus rice. In case of climate variables, the highest mean maximum temperature is found for the Aus growing period and the lowest mean minimum temperature is noticed for Boro growing season. In contrast, mean seasonal rainfall is the highest for Aman growing period), while it is the lowest for the Boro growing period. However, in case of humidity, the highest mean percentage of humidity is detected in Aman growing season, whereas the lowest percentage is detected for the Boro growing period.

In addition to examining descriptive statistics graphs have been also constructed with time $(\mathrm{t})$ as an explanatory variable to observe the spectacular impression about the variations and changes in trend (upward or downward) among the five climatic variables over the whole period (1972-2014) (Figures 1-5). Mean maximum temperature fluctuated greatly, but the overall trend was observed to increase for all the rice growing seasons 
(Figure 1). Small variations were noticed in case of average minimum temperature; however, the trend still appeared to be increasing (Figure 2). Average rainfall in the Aus and Aman rice growing seasons showed upward trends with distinct and maximum fluctuations. The Boro rice season did not reveal any distinct trend over time, but the variations would be seriously affected in case of Aus and Aman crops (Figure 3). Average seasonal humidity also showed an increasing trend with minor fluctuations (Figure 4). Remarkably, Boro yield exhibited an increasing (upward) trend for throughout the seasons with greater deviations compare to Aus and Aman rice yield (Figure 5).

Stationarity Tests. Since the present research paper focuses a model to analyze the effects of climate variation on different rice crops, we need to confirm zero degree of integration for each variable under study. Otherwise, the variables cannot be used for correlation, causality, and OLS estimations if they characterize different degrees of integration. Thus, first we need to make sure that the data series are free of unit roots, i.e. the series are stationary to make all results valid and all estimates consistent (Enders, 1995). In this regard, we have chosen two widely used methods: Augmented Dickey-Fuller (ADF) test (Dickey and Fuller, 1979) and Phillips-Perron (PP) test (Phillips and Perron, 1988) to check the presence of unit roots in the data series and the outputs were presented in table 3. Once stationarity in all variables is confirmed, we can run our comprehensive regression model.

Table 3 - Results of Unit Root Test (Augmented Dickey-Fuller \& Phillips-Perron Tests)

\begin{tabular}{cccc}
\hline Variables & Integration of order for & $\begin{array}{c}\text { Integration of order for } \\
\text { Aman }\end{array}$ & Integration of order for Boro \\
\hline $\operatorname{InY}$ & Aus & $I(1)$ & $\mathrm{I}(1)$ \\
InmaxT & $\mathrm{I}(1)$ & $\mathrm{I}(0)$ & $\mathrm{I}(0)$ \\
InminT & $\mathrm{I}(0)$ & $\mathrm{I}(0)$ & $\mathrm{I}(0)$ \\
InTrain & $\mathrm{I}(0)$ & $\mathrm{I}(0)$ & $\mathrm{I}(0)$ \\
InHum & $\mathrm{I}(0)$ & $\mathrm{I}(0)$ & $\mathrm{I}(1)$ \\
\hline
\end{tabular}

Note: MacKinnon (1996) one-sided p-values (at 1\%, 5\% \& 10\% level is $-3.605,-2.936 \&-2.606$ respectively) is used.

Source: Authors own estimation based on BMD, BBS and DAE.

As we see from the table 3 that Aus, Aman and Boro rice yields are integrated of order one, i.e., I(1), which indicates the existence of unit root in the three data series. However, in case of explanatory variables, humidity showed integration of order I(1) and the rest of the climate variables are integrated of order zero, i.e., I(0), thus these data series are stationary in their level form. According to McCarl et al., (2008) the variables with I(1) must be differenced first before estimation. Since most of the variables are not integrated at the same order under each model, we cannot make a Johansen co-integration test, rather a multiple regression analysis using OLS method with the differenced variables is performed (Gujrati, 2004). On top of that, yield variation of different rice crops are assumed to be caused by climatic variables rather than the vice versa (Lobell and Field, 2007). Therefore, a causality test is also not performed.

\section{RESULTS AND DISCUSSION}

The Regression Results for the Aus Rice Model. The OLS method is employed to identify the impacts of climate variation (i.e., InmaxT, InminT, InTrain and InHum) on the yield of Aus rice $(\ln Y)$ and the results are presented in table 4.

The empirical results expose that the yield of Aus rice is statistically significant and suggests that, climate variables are able to explain some of the variation in the yield of Aus rice. The value of adjusted $R^{2}$ implied that $33 \%$ of the total variation in the yield of Aus rice can be explained by our climate variables (i.e., climatic change) included in the model. The results also indicate that (seasonal average) maximum temperature, rainfall and humidity are statistically significant at $10 \%, 5 \%$ and $1 \%$ level respectively. 
Table 4 - Estimation Results of the Aus Rice Model

\begin{tabular}{lrrrrc}
\hline Dependent Variable: LNYAUS & \multicolumn{7}{c}{ Prob. } & Significance \\
\hline \hline \multicolumn{1}{c}{ Variable } & Coefficient & Std. Error & t-Statistic & Pron \\
\hline \hline LNMAXT & -4.959674 & 2.880848 & -1.721602 & 0.0933 & $*$ \\
LNMINT & 0.478770 & 0.598146 & 0.800424 & 0.4284 & $*$ \\
LNTRAIN & 0.698511 & 0.279758 & 2.495735 & 0.0188 & $* *$ \\
LNHUM & 5.866433 & 1.860465 & 3.153207 & 0.0031 & $* *$ \\
C & -42.33317 & 10.63417 & -3.980861 & 0.0003 & \\
\hline \hline R-squared & 0.386375 Mean dependent var & & 0.194381 & \\
Adjusted R-squared & 0.330730 S.D. dependent var & & 0.275511 & \\
S.E. of regression & 0.228736 Akaike info criterion & & -0.003556 & \\
Sum squared resid & 1.988159 Schwarz criterion & & 0.201235 & \\
Log likelihood & 5.076449 Hannan-Quinn criter. & 0.071965 & \\
F-statistic & 5.733503 Durbin-Watson stat & & 1.564123 & \\
Prob(F-statistic) & 0.001035 & & & \\
\hline \hline
\end{tabular}

Note: ${ }^{*},{ }^{* *}$ and ${ }^{* * *}$ represents the $10 \%, 5 \%$ and $1 \%$ level of significance respectively.

Source: Output from Eviews 7.0

The results further indicate that the rainfall and humidity shows positive association with the yield of Aus rice, whereas Aus yield is negatively related with maximum temperature. It means that an increase of average maximum temperature will further reduce the yield of Aus rice, however rainfall and humidity is beneficial for the Aus yield. Finally minimum temperature could not influence the yield of Aus rice since the coefficient of InminT is statistically insignificant.

The Regression Results for the Aman Rice Model. The Aman rice is almost entirely rain-fed crop and is grown in the season of monsoon. The contribution of the climate variables (InmaxT, InminT, InTrain and InHum) on the yield of Aman rice is obtained from OLS method and is reported in table 5.

Table 5 - Estimation Results of the Aman rice model

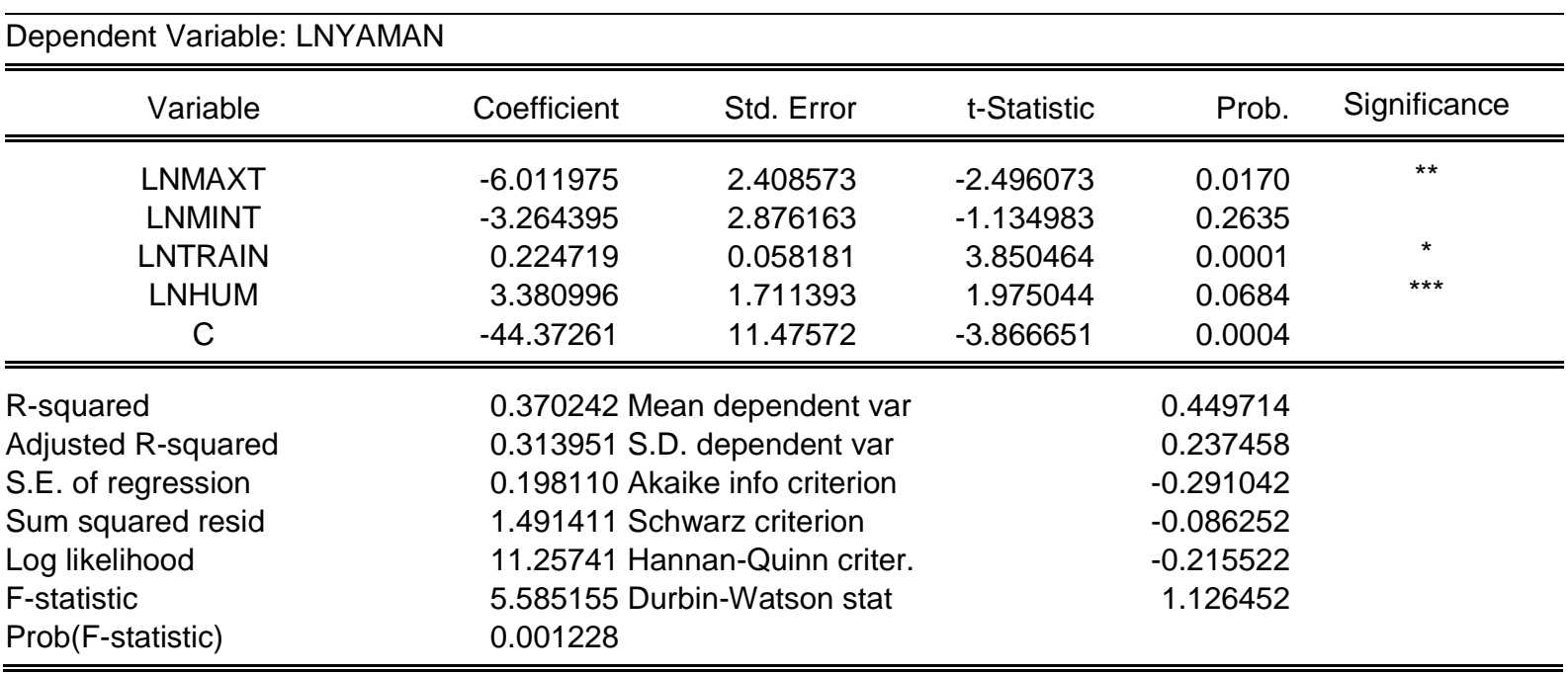

Note: *, ** and ${ }^{* * *}$ represents the $10 \%, 5 \%$ and $1 \%$ level of significance respectively.

Source: Output from Eviews 7.0

The results of the table 5 indicate that, seasonal rainfall and humidity are statistically significant at 10\%, and $1 \%$ significance level respectively and affect Aman rice yield positively. However, maximum temperature negatively contributed to the yield of Aman rice 
and statistically significant at $5 \%$ level. In contrast, minimum temperature is statistically insignificant and have no effect at all on the Aman yield Furthermore, the estimated value of adjusted $R^{2}$ indicated that about $31 \%$ of the total variation in the Aman rice yield can be explained by the climate variables (i.e., variation) used under study.

The Regression Results for the Boro Rice Model. The OLS method is performed to determine the climate change effect on Boro rice yield and the findings are presented in table 6.

Table 6 - Estimated Results of the Boro rice model

\begin{tabular}{|c|c|c|c|c|c|}
\hline \multicolumn{6}{|c|}{ Dependent Variable: LNYBORO } \\
\hline Variable & Coefficient & Std. Error & t-Statistic & Prob. & Significance \\
\hline LNMAXT & -1.686771 & 0.950550 & -1.773799 & 0.0985 & * \\
\hline LNMINT & 3.506088 & 0.914076 & 3.829386 & 0.0233 & ** \\
\hline LNTRAIN & -0.182657 & 0.094014 & -1.942864 & 0.0595 & * \\
\hline LNHUM & 5.033605 & 0.853148 & 5.900034 & 0.0000 & *** \\
\hline C & -25.61081 & 5.339903 & -4.796119 & 0.0000 & \\
\hline R-squared & \multicolumn{3}{|c|}{0.515751 Mean dependent var } & 0.990259 & \\
\hline Adjusted R-squared & \multicolumn{3}{|c|}{0.464777 S.D. dependent var } & 0.235490 & \\
\hline S.E. of regression & \multicolumn{3}{|c|}{0.172282 Akaike info criterion } & -0.570427 & \\
\hline Sum squared resid & \multicolumn{3}{|c|}{ 1.127878 Schwarz criterion } & -0.365636 & \\
\hline Log likelihood & \multirow{2}{*}{\multicolumn{3}{|c|}{$\begin{array}{l}\text { 17.26417 Hannan-Quinn criter. } \\
\text { 10.11800 Durbin-Watson stat }\end{array}$}} & -0.494906 & \\
\hline F-statistic & & & & 1.619417 & \\
\hline Prob(F-statistic) & \multicolumn{3}{|l|}{0.000011} & & \\
\hline
\end{tabular}

Note: ${ }^{*},{ }^{* *}$ and ${ }^{* * *}$ represents the $10 \%, 5 \%$ and $1 \%$ level of significance respectively.

Source: Output from Eviews 7.0

The empirical results show that, seasonal average maximum temperature and rainfall negatively associated with Boro rice yield and highly significant at 10 significance level. This also implies that rise in maximum temperature and rainfall could have an adverse effect on Boro yield. However, average minimum temperature and humidity directly influence the yield of Boro rice and statistically significant at $5 \%$ and $1 \%$ level respectively. Furthermore, the value of adjusted $\mathrm{R}^{2}$ indicate that the long-run overall model well fitted as the explanatory variables (i.e., climatic variables) can explain over $46 \%$ of the total variation in the yield of Boro rice (i.e., dependent variable).

Findings of the study also implies that $1 \%$ increase in growing season maximum temperature and rainfall on average will reduce the yield of Boro rice by 1.68 and 0.18 metric ton/hectare respectively. On the other hand, $1 \%$ increase in minimum temperature and humidity on average could raise Boro rice yields by 3.50 and 5.03 metric tons/hectare respectively.

\section{CONCLUSION}

The overall objective of this study is to assess the climate change impacts on the yield of three different rice crops (namely, Aus, Aman and Boro) in Bangladesh using time series data for the period 1972-2014. The OLS regression method was applied to satisfy this objective. The overall findings of the study indicate that all four climate variables have substantial effects on the yields of Aus, Aman and Boro rice. In the case of Aus rice, average seasonal rainfall and humidity are found statistically significant and directly associated with Aus yield. In contrast, the average seasonal maximum temperature negatively influence the yield of Aus rice. In addition to this, for the Aman rice, three climate variables (average seasonal maximum temperature, rainfall and humidity) is found statistically significant. However, the directions of the effects is not identical. Average seasonal rainfall and humidity 
are observed as positively affecting the yield of this crop, since Aman fully rain-fed crop and it grows well in humid (i.e., moist) conditions during the monsoon season. On the other hand, (average seasonal) maximum temperature have an adverse effect on the yield of Aman rice, as we know Aman rice require supplementary irrigation during plantation depending on weather. The influence of average seasonal maximum temperature is also observed to be identical for the yield of Boro rice and the relation is inverse. However, average seasonal minimum temperature and humidity exposed positive association with Boro rice yield. The results further indicates that average seasonal maximum temperature and rainfall are statistically significant and negatively affect the yield of Boro rice. In terms of the $\mathrm{R}^{2}$ and $\mathrm{F}$ values, all three rice models have been found statistically significant and the results of overall goodness of fit were consistent with the results of Lobell (2010). Every crop has an optimum minimum and maximum temperatures, rainfall and humidity limit for their reproductive and vegetative growth. When temperature exceeded the upper limit or falls below the range or humidity crossed the upper limit, crop production changes drastically. Moreover, excessive rainfall may create water logging condition and flooding that also destroys the crop production. Given the high vulnerability of rice yields to climate variations in Bangladesh, different adaptation strategies should be adopted to offset the adverse effects of climate change. Climate change in Bangladesh is a serious concern since it adversely affects agriculture which is an important sector in the country. Therefore, the concerned authority should take appropriate policies to fight against the climate change impact on rice production to ensure food security for the ever increasing population of the country through implementing sustainable agricultural development. Last but not the least, national level data might not portray the real scenario of the regional variations of climate change and their effects on crop yield (Lobell et al., 2007). Therefore, future research in this field should focus on regional specific data analysis to capture the regional variations of climate change and to obtain a more comprehensive scenario of climate changes and their impacts on rice yield in Bangladesh. Moreover, researchers of this field may be induced by the government to go for further researches on adaptation of temperature-tolerant rice varieties in the specific region of Bangladesh.

\section{REFERENCES}

1. Adams, R., Fleming, R., Chang, C., McCarl, B., Rosenzweig, C., 1995. A reassessment of the economic effects of global climate change on US agriculture. Clim. Change 30, $146-167$.

2. Ali, A., 1999. Climate change impacts and adaptation assessment in Bangladesh. Clim. Res. 12, 109-116.

3. Agrawala, S.T.O.; Ahmed, A.U.; Smith, J.; Aalst, 2003. M.V. Development and Climate Change in Bangladesh: Focus on Coastal Flooding and the Sunderbans; Organisation for Economic Co-operation and Development (OECD): Paris, France.

4. Ahmed, A.U., 2006. Bangladesh Climate Change Impacts and Vulnerability. A Synthesis; Climate Change Cell, Department of Environment, CDMP, Government of the People's Republic of Bangladesh, Dhaka, Bangladesh.

5. Almaraz, J.J., Mabood, F., Zhou, X., Gregorich, E.G., Smith, D.L., 2008. Climate change, weather variability and corn yield at a higher latitude locale: South-western Quebec. Clim. Change 88, 187-197.

6. Awal, M.A.; Siddique, 2011. M.A.B. Rice Production in Bangladesh Employing by ARIMA Model. Bangladesh Journal of Agricultural Research. 36, 51-62.

7. Ahmed, A.;2001 Ryosuke, S. Climate Change and Agricultural Food Production of Bangladesh: An Impact Assessment Using GIS-Based Biophysical Crop. Simulation Model; Center for Spatial Information Science, University of Tokyo: Komaba, Japan.

8. BER (Bangladesh Economic Review), 1991, Department of Finance, Ministry of Finance, Government of the People's Republic of Bangladesh, Dhaka.

9. BBS (Bangladesh Bureau of Statistics), 2008. Compendium of Environment Statistics of Bangladesh. Government of Bangladesh, Dhaka, Bangladesh. 
10. BBS (Bangladesh Bureau of Statistics), 2011. Statistical Year Book of Bangladesh. 201112, Planning Division, Ministry of Planning, Government of the People's Republic of Bangladesh. www.bbs.gov.bd [Accessed on January 27, 2015]

11. BBS (Bangladesh Bureau of Statistics), 2012. Statistical Year Book of Bangladesh. 201213, Planning Division, Ministry of Planning, Government of the People's Republic of Bangladesh. www.bbs.gov.bd [Accessed on January 27, 2015]

12. BBS (Bangladesh Bureau of Statistics), 2014. Data Collected from Statistics and Informatics Division (SID), Ministry of Planning, Government of Bangladesh, Dhaka, Bangladesh. Available at: http:// www.bbs.gov.bd [Accessed on :02 January 2015]

13. Bangladesh Bank. 2014, Annual Report 2013-14. Dhaka, Bangladesh: Available at: http:// www.bangladesh-bank.org/econdata/index.php [Accessed 2 February 2015]

14. BRRI (Bangladesh Rice Research Institute), 1991. Success history: Varietals Development. Gazipur, Bangladesh. http://brri.gov.bd/ success stories/index.htm [ Accessed on June 27, 2014]

15. Basak, J.K., Ali, M.A., Islam, M.N., Rashid, M.A., 2010. Assessment of the effect of climate change on Boro rice production in Bangladesh using DSSAT model. J. Civ. Eng. 38, 95-108.

16. Basak, J. K. , Titumir, R. A. M., Biswas, J. K., Mohinuzzaman, M.,2013. Impacts of Temperature and Carbon dioxide on Rice yield in Bangladesh. Bangladesh Rice J. 17(1\&2): 15-25.

17. Begum, M.E.A.; D'Haese, L., 2010. Supply and Demand Situations for Major Crops and Food Items in Bangladesh. J. Ban. Agric. Univ. 8, 91-102.

18. Boubacar, I., 2010. The effects of drought on crop yields and yield variability in Sahel. The Southern Agricultural Economics Association Annual Meeting: The Southern Agricultural Economics Association, Orlando FL.

19. BMD (Bangladesh Meteorological Department), 2014. Data Collected from BMD Headquarter at Dhaka (Climate Section) on January 31, 2015, Bangladesh.

20. Chang, C.C., 2002. The potential impact of climate change on Taiwan's agriculture. Agric. Econ. 27, 51-64.

21. Chen, C. C., McCarl, B. A., and Schimmelpfennig, D. E., 2004. Yield variability as influenced by climate: A statistical investigation. Climate Change, 66, 239-261.

22. Carew, R., Smith, E. G., and Grant, C., 2009. Factors influencing wheat yield and variability: Evidence from Manitoba, Canada. Journal of Agriculture and Applied Economics, 41(3), 625-639.

23. Cabas, J., Weersink, A., Olale, E., 2010. Crop yield response to economic, site and climate variables. Clim. Change 101, 599-616.

24. DAE (Directorate of Agricultural Extension), 2013. Government of the People's Republic of Bangladesh. Ministry of Agricultural, Dhaka, Bangladesh.

25. Deressa, T.T., Hassan, R.M., 2009. Economic impact of climate change on crop production in Ethiopia: evidence from cross-section measures. J. Afr. Econ. 18, 529-554.

26. Dickey, D.A. and Fuller, W.A, (1979). Distributions of the estimators for autoregressive time series with a unit root, Journal of American Statistical Association, 74: 427- 431.

27. Enders, W. (1995). Applied Econometric Time Series, John Wiley \& Sons, Inc New York.

28. Ferdous, M.G.; Baten, M.A., 2011. Climatic Variables of 50 Years and their Trends over Rajshahi and Rangpur Division. J. Environ. Sci. Nat. Res. 4, 147-150.

29. Gbetibouo, G.A., Hassan, R.M., 2005. Measuring the economic impact of climate change on major South African crops: a Ricardian approach. Global Planet. Change 47, 143152.

30. Granger, O.E., 1980. The impact of climate variation on the yield of selected crops in three California countries. Agric. Meteorol. 22, 367-386.

31. Gujrati, D., 2004. Basic Econometrics, fourth edition. The McGraw-Hill, New York, USA.

32. Hossain A, Teixeira da Silva JA, Lozovskaya MV, Zvolinsky VP., 2012. The effect of high temperature stress on the phenology, growth and yield of five wheat (Triticum aestivum L.) genotypes. The Asian and Australasian Journal of Plant Science and Biotechnology 6: 14-23. 
33. Holst, R., Yu, X., and Grun, C., 2010. Climate change, risk and grain production in China. AAEA, CAES, WAEA joint annual meeting (p. 29). Agriculture and Applied Economics Association, Colorado.

34. Haim, D., Shechter, M., Berliner, P., 2008. Assessing the impact of climate change on representative field crops in Israel agriculture: a case study of wheat and cotton. Clim. Change 86, 425-440.

35. Hossain, M.K., T.A. Masron, A.A. Kamil, A. Mustafa and M.A. Baten, 2012. Influence of environmental constraints on rice productive technical efficiency in Bangladesh. Proceedings of the International Conference on Management, Economics and Finance, October 15-16, 2012, Hilton Hotel, Kuching, Sarawak, Malaysia.

36. Isik, M., \& Devadoss, S., 2006. An analysis of the impact of climate change on crop yields and yield variability. Applied Economics, 38, 835-844.

37. Intergovernmental Panel on Climate Change (IPCC), 2007. Climate Change: Impacts, Adaptation and Vulnerability. In Contribution of Working Group II to the Fourth Assessment Report of the Intergovernmental Panel on Climate Change; Cambridge University Press: Cambridge, UK.

38. Lansigan, F.P., de los Santos, W.L., Coladilla, J.O., 2000. Agronomic impacts of climate variability on rice production in the Philippines. Agric. Ecosyst. Environ. 82, 129-137.

39. Lobell, D. B., and Asner, G. P., 2003. Climate and management contributions to recent trends in U.S. agricultural yields. Science, 299(5609), 1032.

40. Lobell, D.B., Cahill, K.N., Field, C.B., 2007. Historical effects of temperature and precipitation on California crop yields. Clim. Change 81, 187-203.

41. Lobell, D. B., and Field, C. B., 2007. Global scale climate-crop yield relationships and the impacts of recent warming. Environmental Research Letters, 2(1), 1-7.

42. Lobell, D.B., Burke, M.B., Tebaldi, C., Mastrandrea, M.D., Falcon, W.P., Naylor, R.L., 2008. Prioritizing climate change adaptation needs for food security in 2030 . Science 319, 607-610.

43. Lobell, D., 2010. Crop response to climate: time-series models. In: Lobell, D., Burke, M. (Eds.), Climate Change and Food Security. Springer, Dordrecht, pp. 85-98.

44. Karim, Z., S.G. Hussain and M. Ahmed, 1996. Assessing impact of climate variations on food grain production in Bangladesh. Water Air Soil Pollut., 92: 53-62.

45. Kabubo-Mariara, J.K.; Karanja, F.K., 2007. The Economic Impact of Climate Change on Kenyan Crop Agriculture: A Ricardian Approach. Glob. Planet. Chang. 57, 319-330.

46. Kurukulasuriya, P., Ajwad, M.I., 2007. Application of the Ricardian technique to estimate the impact of climate change on smallholder farming in Sri Lanka. Clim. Change 81, 3959.

47. Kaiser, H.M., Riha, S.J., Wilks, D.S., Rossiter, D.G., Sampath, R., 1993. A farm-level analysis of economic and agronomic impacts of gradual climate warming. Am. J. Agric. Econ. 75, 387-398.

48. Kim, M. K., and Pang, A., 2009. Climate change impact on rice yield and production risk. Journal of Rural Development, 32(2), 17-29.

49. MacKinnon, James, G. (1996). Numerical Distribution Functions for Unit Root and Cointegration Tests, Journal of Applied Econometrics, 11, 601-618.

50. Mahmood, R., 1997. Impacts of Air Temperature Variations on the Boro Rice Phenology in Bangladesh: Implications for Irrigation Requirements. Agric. For. Meteorol., 84, 233247.

51. Mahmood, R., 1998. Air temperature variations and rice productivity in Bangladesh: a comparative study of the performance of the Yield and CERES-Rice models. Ecol. Model. 106, 201-212.

52. Ministry of Finance (MoF). 2011, Bangladesh Economic Review FY 2011-12. Dhaka, Bangladesh: Finance Division, Ministry of Finance, Government of Bangladesh. Available at: http://www.mof.gov.bd/en/index.php [Accessed 11 February 2015]

53. Ministry of Finance (MoF). 2012, Bangladesh Economic Review FY 2012-13. Dhaka, Bangladesh: Finance Division, Ministry of Finance, Government of Bangladesh. Available at: http://www.mof.gov.bd/en/index.php [Accessed 11 February 2015] 
54. Ministry of Finance (MoF). 2013, Bangladesh Economic Review FY 2013-14. Dhaka, Bangladesh: Finance Division, Ministry of Finance, Government of Bangladesh. Available at: http://www.mof.gov.bd/en/index.php [Accessed 11 February 2015]

55. McCarl, B. A., Adams, R. M., and Hurd, B. H., 2001. Global climate change and its impact on agriculture. Texas A\&M University, Texas, USA.

56. McCarl, B.A., Villavicencio, X., Wu, X., 2008. Climate Change and future analysis: is stationarity dying? Am. J. Agric. Econ. 90, 1241-1247.

57. Mendelsohn, R., Nordhaus, W., Shaw, D., 1994. The impact of global warming on agriculture: a Ricardian analysis. Am. Econ. Rev. 84, 753-771.

58. Mendelsohn, R., 2009. The impact of climate change on agriculture in developing countries. Journal of Natural Resources Policy Research, 1(1), 5-19.

59. Moula, E.L., 2009. An empirical assessment of the impact of climate change on smallholder agriculture in Cameroon. Global Planet. Change 67, 205-208.

60. Phillips, P. C., Perron, P. (1988). Testing for a Unit Root in Time Series Regression. Biometrika. 75(2), 335-46.

61. Paul, B.K., 1998. Coping mechanism practiced by drought victims (1994/5) in North Bengal, Bangladesh. Appl. Geogr. 18, 355-373.

62. Peng, S., Huang, J., Sheehy, J. E., Laza, R. C., Visperas, R. M.,Zhong, X., 2004. Rice yields decline with higher night temperature from global warming. Proceedings of the National Academy of Science (PNAS), 101(27), 9971-9975.

63. Rahman, M.S., 2000. A rainfall simulation model for agricultural development in Bangladesh. Discrete Dynam. Nat. Soc. 5, 1-7.

64. Rashid, H.E., 1991. Geography of Bangladesh. University Press, Dhaka, Bangladesh.

65. Rashid, M.H., Islam, M.S., 2007. Adaptation to Climate Change for Sustainable Development of Bangladesh Agriculture. Bangladesh Country Paper, APCAEM, November, 2007.

66. Rahman, M.W.; Parvin, L., 2009. Impact of Irrigation on Food Security in Bangladesh for the Past Three Decades. J. Water Res. Prot. 3, 216-225.

67. Reilley, J., Watson, R., Zinyowera , M., Moss, R., \& Dokken, D., 1996. Agriculture in a Changing Climate: Impacts and Adaptations. IPCC.

68. Rimi, R.H.; Rahman, S.H.; Karmakar, S.; Hussain, S.G., 2009. Trend Analysis of Climate Change and Investigation on its Probable Impacts on Rice Production at Sathkhira, Bangladesh. Pak. J. Meteorol. 6, 37-50.

69. Rosenzweig, C., 1989. Global climate change: predictions and observations'. Am. J. Agric. Econ. 71, 1265-1271.

70. Schmidhuber, J., and Tubiello, F. N., 2007. Global food security under climate change. Proceedings of the National Academy of Science (PNAS), 104(50), 19703-19708.

71. Schlenker, W., and Roberts, M. J., 2008. Estimating the impact of climate change on crop yields: The importance of non-linear temperature effects. NBER Working Paper 13799, National Bureau of Economic Research, Massachusetts, USA.

72. Sarker, M.A.R.; Alam, K.; Gow, J., 2014. Assessing the effects of climate change on rice yields: An econometric investigation using Bangladeshi panel data. Economic Analysis \& Policy, 44(4), 405-416.

73. Sarker, M.A.R.; Alam, K.; Gow, J., 2012. Exploring the Relationship between Climate Change and Rice Yield in Bangladesh: An Analysis of Time Series Data. Agricultural Systems 112, 11-16.

74. Sarker, M.A.R., 2012. Impacts of Climate Change on Rice Production and Farmers' Adaptation in Bangladesh. Ph.D. Thesis, University of Southern Queensland, Toowoomba, Australia.

75. Sanghi, A., Mendelsohn, R., 2008. The impact of global warming on farmers in Brazil and India. Global Environ. Change 18, 655-665.

76. Stooksbury, D. E., and Michaels, P. J., 1994. Climate change and large-area corn yield in the Southeastern United States. Agronomy Journal, 86(3), 564-569.

77. UNDP (United Nations Development Program), 2008. Fighting Climate Change: Human Solidarity in a Divided World. Human Development Report. Oxford University Press. 
78. Wang, J., Mendelsohn, R., Dinar, A., Huang, J., Rozelle, S., Zhang, L., 2009. The impact of climate change on China's agriculture. Agric. Econ. 40, 323-337.

79. You, L., Rosegrant, M. W., Fang, C., and Wood, S., 2005. Impact of global warming on Chinese wheat productivity. International Food Policy Research Institute (IFPRI), Washington DC, USA.

\section{APPENDIX}

Trend of Average Maximum Temperature $\left({ }^{\circ} \mathrm{C}\right)$

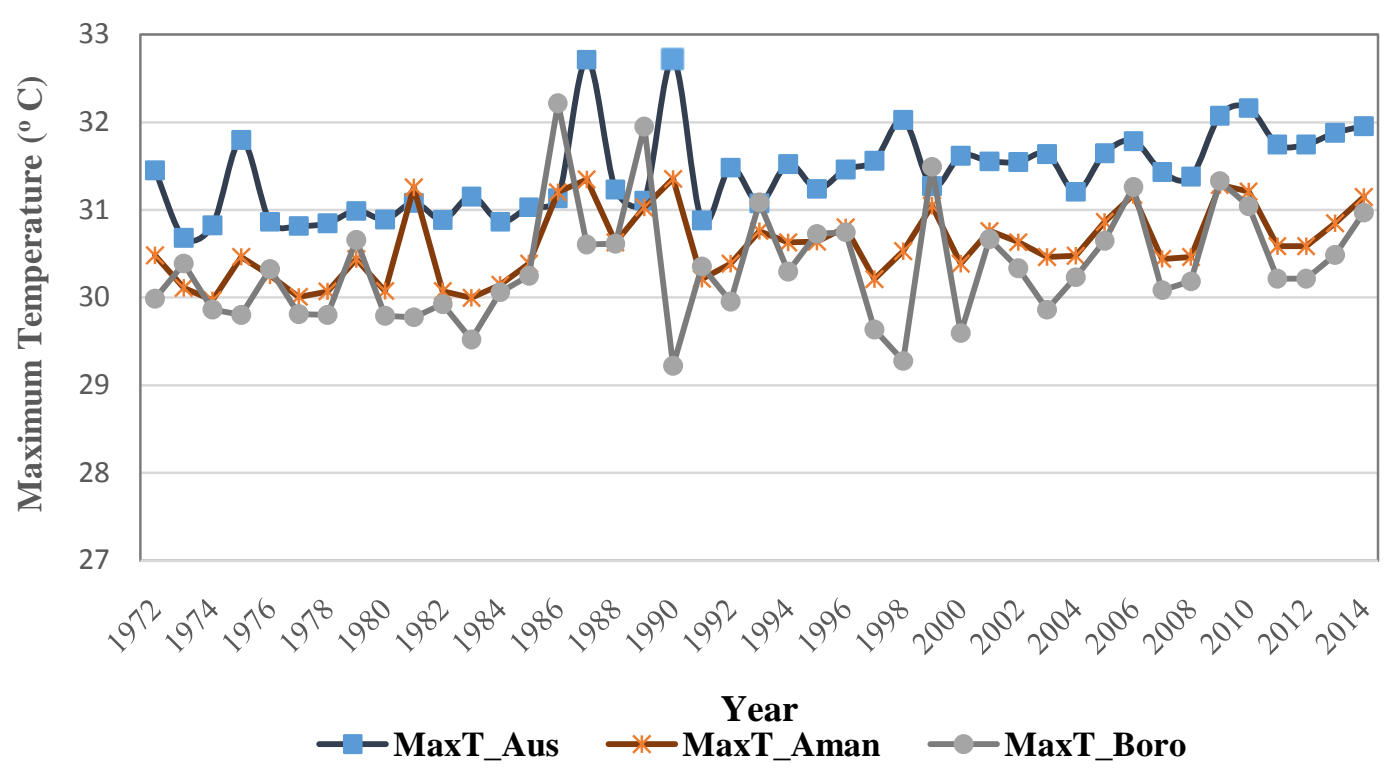

Figure 1 - Trends and variations in the average seasonal maximum temperature $\left({ }^{\circ} \mathrm{C}\right)$ for 1972-2014

\section{Trend of Average Minimum Temperature $\left({ }^{\circ} \mathrm{C}\right)$}

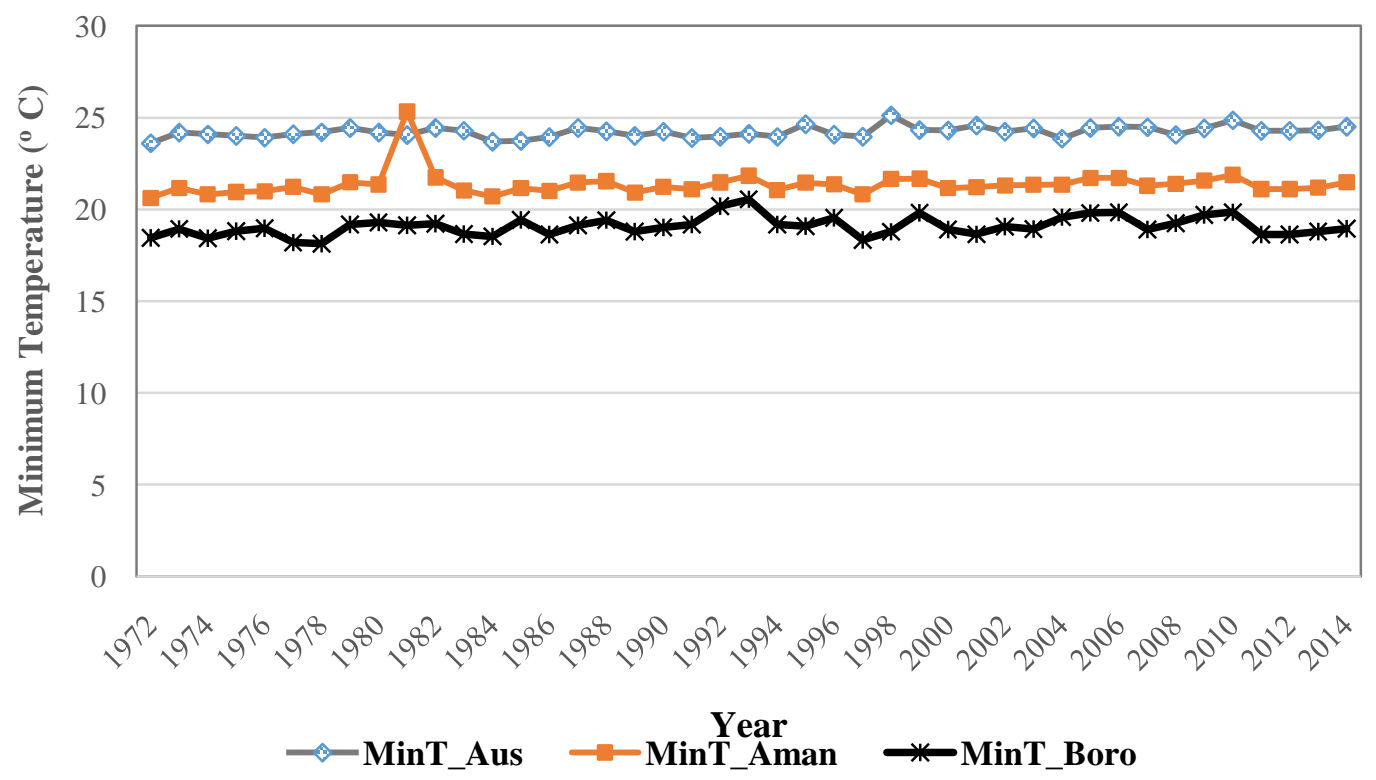

Figure 2 - Trends and variations in the average seasonal minimum temperature $\left({ }^{\circ} \mathrm{C}\right)$ for 1972-2014 


\section{Trend of Seasonal Average Rainfall (in mm)}

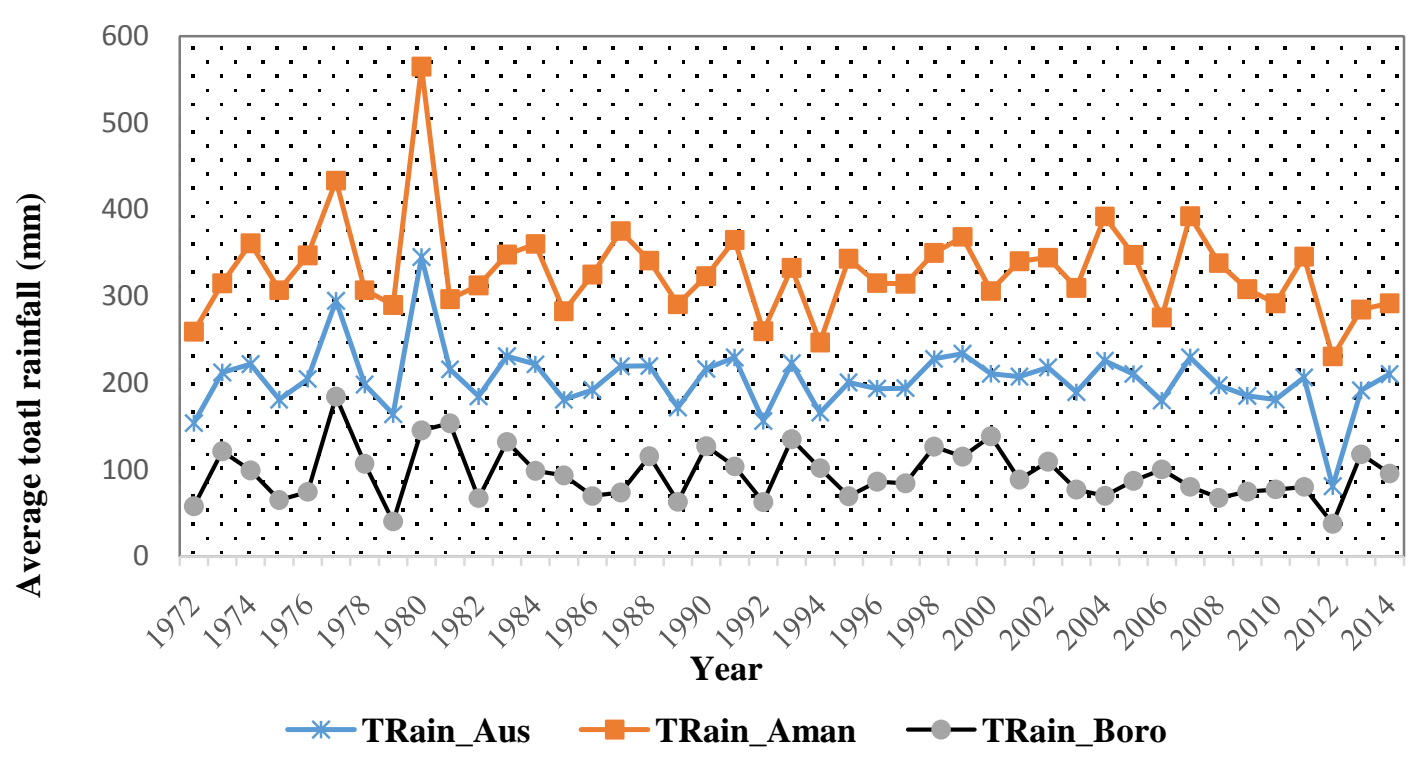

Figure 3 - Trends and variations in the average seasonal rainfall (in $\mathrm{mm}$ ) for the period 1972-2014

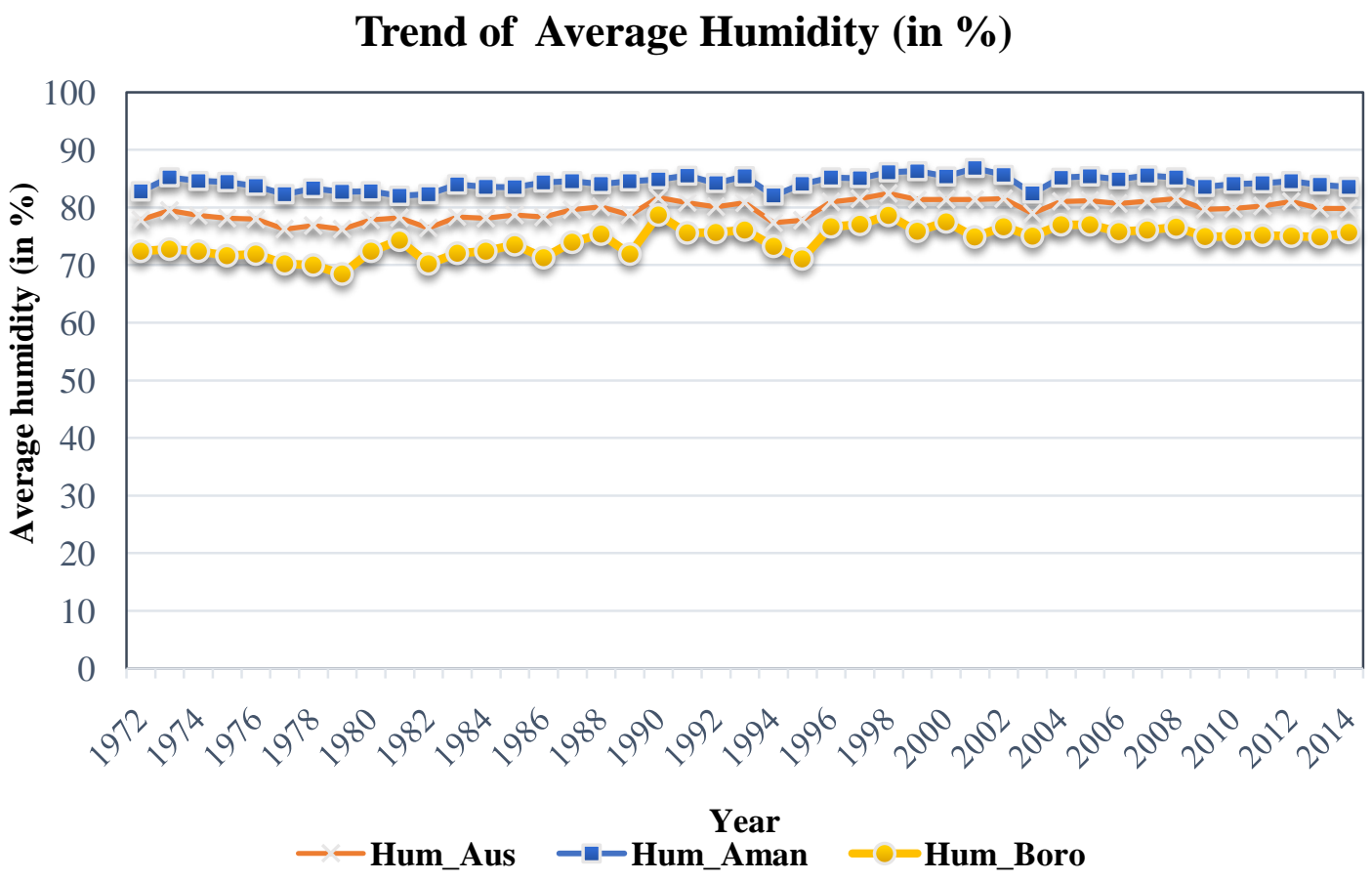

Figure 4 - Trends and variations in the average humidity (in \%) for the period 1972-2014 


\section{Trend of Average Yield (ton/hac)}

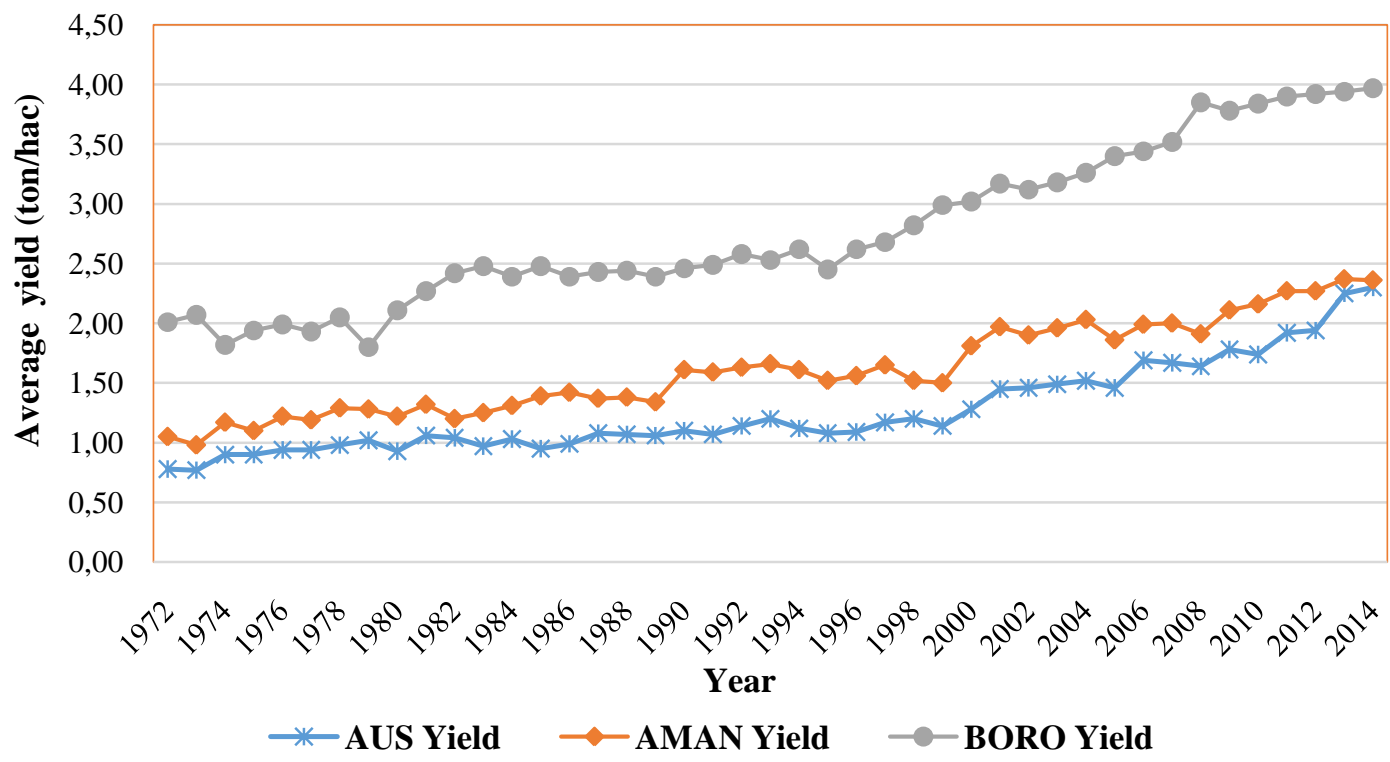

Figure 5 - Trends and variations in the average yield (ton/hac) of different rice crops for 1972-2014 